\title{
WHAT'S IN A NAME? SUGGESTIONS FOR REVISIONS TO THE TERMINOLOGY OF KIMBERLITES AND LAMPROPHYRES FROM A GENETIC VIEWPOINT.
}

Roger H. Mitchell.

\section{Department of Geology, Lakehead University, Thunder Bay, Ontario, Canada P7B 5E1.}

Our understanding of the petrogenesis of alkaline rocks has been considerably advanced by the application of modern methods of analysis to the determination of the chemical and isotopic composition of rocks and minerals. Unfortunately, these advances have not been matched by
changes in our approach to the terminology of alkaline
rocks. Modal classifications have unchanged since the legacy hinders our understanding of the This terminological relationships between diverse groups the actual genetic unfortunately leads to inappropriate petrogenetic rocks and speculation.

Why do we attempt to classify rocks?. One reason is to give a particular assemblage of minerals a name, this being a convenient way of informing other petrologists of the context. However arises from the operaticular assemblage of minerals upon a particular magma type and ogenetic processes acting association. Correct classification not a fortuitous random if the object of the exercise is ultimately to thus vital petrogenesis. In the past different names have understand to the same mineral assemblage or the same name been applied to rocks which differ in their mineralogy. Commonls applied has led to the "recognition" of incorrect association this to suggestions of consanguineity proposal that many alkaline rocks may be grouped in The lamprophyre clan is but one example of this aped in a terminology.

Existing IUGS-sanctioned non-genetic classifications are unsatisfactory for many alkaline rocks e.g., minettes versus phlogopite sanidine lamproites or carbonatites gersus calcite kimberlites. Consequently mineralogicalgiven alkaline rock is based upon: in which the name of assemblage present, (2) compositi (1) the total mineral minerals and (3) in some instances the data for these composition. The objective of this the whole rock isotopic the parental magma which has this approach is to identify rocks. Hence, alkaline rocks given rise to a suite of clans. Individual rocks are not considered to petrological isolation from other rocks in a considered or named in parental magma type is reflected in the nomenclature by clan name e.g. kimberlite, lamproite, melilitite et by a Modally diverse, but consanguing described by modal varietal members of a clan are phlogopite lamproite, leucite diopside lamproite. olivine

Application of this approach to rocks which contain diamond suggests that there are three genetically-distinct upper mantle-derived magmas which are capable of transporting diamond xenocrysts; kimberlite (formerly group I kimberlite), orangeite (formerly group II kimberlite) and lamproite. Group II kimberlites are renamed as they apparently form a petrological clan that is genetically- 
unrelated to group I kimberlites. The rocks now known as group II kimberlites were originally termed (micaceous) kimberlites on the basis of the presence in them of diamond. It is unlikely that if this group of rocks were discovered today they would be termed kimberlites as they have few mineralogical similarities with archetypal group I kimberlites.

The term lamprophyre was introduced as a field term in the nineteenth century to describe hypabyssal rocks that are rich in mica. Usage was confined to describing the macroscopic appearance of the rocks. Subsequently, the term was broadened to include any dike rocks containing mafic phenocrysts (mica, amphibole, pyroxene) set in a felsic groundmass. The term was, and still is, used indiscriminately in this descriptive manner without regard to the nature of the associated rocks and/or tectonic setting of the occurrence. Recently, diverse lamprophyric rocks, kimberlites and lamproites have all been considered to be members of a "lamprophyre clan". However, the P/T conditions of generation and/or source regions of the magmas which formed these rocks are very different and it follows that the rocks cannot be genetically related. Further, as the concept of a petrological clan requires that members of the clan be consanguineous it is evident that the concept of a "lamprophyre clan" is petrologically unsound as there is no universal lamprophyre magma type.

Application of mineralogical-genetic terminology to diverse rocks described as lamprophyres confirms that many varieties are derived from genetically-unrelated magma types. Mica-rich rocks of lamprophyric aspect are commonly found as modal variants of rocks formed from several. distinct magma types. They represent rocks that have formed under water-rich or other special conditions relative to other members of the clan. It is proposed here that such rocks be assigned to a "lamprophyre facies". Thus, phlogopite diopside lamproite belongs to the lamprophyre facies of the lamproite clan, whereas sannaite, monchiquite and camptonite are lamprophyric facies of the alkali basalt clan. This concept preserves the original meaning of the term "lamprophyric" and has no genetic connotations.

The lamprophyres facies concept is illustrated by the following examples:

\section{ALKALINE OLIVINE BASALT CLAN}

\section{Facies}

Extrusive(lava)

Hypabyssal

plutonic

Lamprophyric hypabyssal Sannaite, camptonite,
Rock

Basalt

Diabase

Gabbro

Petrographically different members of the lamprophyre

facies result from formation under different volatile, $P / T$ conditions and cooling rates, hence some are heteromorphs. In this clan different facies are easily related to the site and style of crystallization and the lamprophyric facies is entirely hypabyssal. In contrast. in other clans, lava flow or plutonic facies may be of lamprophyric character e.g. the minette lavas of the basanite clan and the phlogopite perovskite pyroxenites of the melilitite clan, respectively. 


\section{GROUP 1 KIMBERLITES}

Facies

Crater

Diatreme

kimberlite

Hypabyssal

- phlogopite apatite kimberlite

In some group I kimberlites simple modal enrichment of phlogopite confers a "lamprophyric aspect" to the rocks. These cases are relatively uncommon and the majority of group I kimberlites have no macroscopic or microscopic lamprophyric character. Note that lamprophyric facies group I kimberlites do not grade in a petrogenetic sense or mineralogical/genetic classification into group II kimberlites or minettes, although the latter may have some gross modal similarities.

\section{LAMPROITE CLAN}

\section{Facies}

Lamprophyric lava

Hypabyssal

Lamprophyric hypabyssal

Plutonic lamproite.

Further examples may be devised with respect to the group II kimberlite, basanite (minettes), melilitite (alnoites, aillikites), nephelinite and "andesitic" (minette, spessartite, kersantite) clans.

Lamprophyres have typically been stigmatized as orphans of dubious and unfathomable antecedents; thus they are consigned by many to the petrological waste basket. Consideration of lamprophyres as a group without regard to their diverse parentage has hindered understanding of their genesis. By adopting the lamprophyre facies concept and using mineralogical/genetic classifications, it is now possible to show that lamprophyres are merely derivatives of common magma types. Using these principles petrologists are hopefully now in a position finally to put this neglected but ubiquitous group of rocks into their correct petrological context. 